\title{
PELAYANAN LEMBAGA ZAKAT UNTUK MENINGKATKAN KEPUASAN MUZAKKI
}

\author{
Karebet Gunawan \\ Sekolah Tinggi Agama Islam Negeri (STAIN) Kudus \\ e-mail:betaguna@gmail.com
}

\begin{abstract}
Zakat is one of the links of a Muslim identity. Zakat not only benefits the recipients, but can provide enormous benefits to those who issue zakat. Zakat institutions basically in providing services must be transparent and can satisfactory to all parties so that it can lead to loyalty of users. Zakat institutions must work how to create the satisfaction of muzakki so that the funds collected more and more. The payment of zakat through one of zakat institutions is a form of tabligh and at the same time gives an example to other parties to implement the teachings of zakat in an organized manner. In addition, zakat institutions should also improve the quality of service so that with good service the zakat institution users will be more loyal. With loyalty it can cause muzakki more tied with zakat institution.
\end{abstract}

Keywords: Transparency, Loyalty, and Zakat Institution

\section{Pendahuluan}

Ancaman bagi yang tidak mau berzakat yaitu hukuman akhirat Rasulullah SAW bersabda: “Tidak ada seorangpun yang memiliki simpanan, kemudian ia tidak mengeluarkan zakatnya, pasti akan dipanaskan simpanannya itu di atas jahannam, 


\section{Karebet Gunawan}

dijadikan cairan panas yang diguyurkan di lambung dan dahinya, sehingga Allah berikan keputusan di antara para hamba-Nya di hari yang lama seharinya sekitar lima puluh ribu tahun, sampai diketahui kemana perjalannya, ke surge atau neraka." (HR. AsySyaikhani). Hukuman duniawi yang telah Allah SWT tetapkan, seperti dalam hadis: "Tidak ada suatu kaum yang menolak zakat, pasti Allah akan uji mereka dengan paceklik (kelaparan dan kekeringan) (HR. Al-Hakim, Al-Baihaqi, dan At-Thabrany). Dalam hadis lain: "Dan mereka tidak menolak zakat hartanya kecuali para malaikat akan mencegah hujan dari langit, dan jika tidak karena hewan ternak mereka tidak akan diberi hujan." (HR. Al-Hakim Ibnu Majah, Al-Bazzar, dan Al-Baihaqi). Sedangkan hukuman duniawi yang ditimpakan pada pemerintah muslim adalah sebagaimana Rasulullah SAW bersabda tentang zakat: “Barang siapa yang memberikannya untuk memperoleh pahala. Dan barang siapa yang menolaknya maka kami akan mengambil separo hartanya, dengan kesungguhan sebagaimana kesungguhan Rabb kami. Tidak halal bagi keluarga Muhamad sedikitpun darinya." (HR. Ahmad, An-Nasa'iy, Abu Daud, dan Al-Baihaqi) (Hafid Fuad Halimi, 2013: 65).

Selain ancaman bagi orang yang tidak zakat maka ada ganjaran bagi orang yang mau mengeluarkan zakat. Allah SWT mendorong kaum muslimin untuk membayar zakat dengan menjelaskan manfaat zakat bagi kebersihan jiwanya. Zakat akan memberikan dampak positif baik bagi pemberi maupun bagi yang menerima. Rasulullah SAW bersabda: "Ada tiga hal yang aku bersumpah maka hafalkanlah: (1) Tidak akan berkurang harta karena bersedekah, (2) tidak ada hambapun yang dizalimi kemudian bersabar, pasti Allah akan menambahkan kemuliaan, (3) tidak ada seorang hambapun yang membuka pintu memintaminta kecuali Allah akan bukakan baginya pintu kefakiran." (HR. At-Tirmidziy). Zakat membersihkan muzakki dari penyakit pelit dan membebaskannya dari penyembahan harta. Keduanya adalah penyakit jiwa yang sangat berbahaya yang membuat manusia 
jatuh dan celaka. Dari itu Allah SWT berfirman yang artinya: "Dan siapa yang dipelihara dari kekikiran dirinya, mereka itulah orangorang yang beruntung." (QS. Al-Hasyr: 9).

Dengan demikian, zakat adalah salah satu mata rantai dari sebuah identitas seorang muslim dan muslimah. Zakat tidak hanya memberi manfaat bagi penerima, melainkan dapat memberi manfaat yang sangat besar bagi orang-orang yang mengeluarkan zakat (Suharsono, 2013: 10). Adapun secara umum, manfaat yang dapat diperoleh oleh muzakki antara lain; zakat mensucikan jiwa dari sifat kikir, zakat mendidik berinfak dan memberi, berakhlak dengan Allah, zakat adalah wujud syukur atas nikamt Allah, zakat mengobati hati dari cinta dunia, zakat mengembangkan kekayaan batin, zakat menarik simpati/cinta, zakat mensucikan harta dari bercampurnya dengan hak orang lain, zakat mengembangkan dan memberkahkan harta. Jelaslah pelajaran yang dapat diambil dari zakat tersebut beberapa hikmah yang besar di dalam kehidupan ummat manusia.

Allah SWT memerintahkan zakat kepada setiap orang Islam yang telah layak berdasarkan hitungan nishab seseorang sehingga menumbuhkan nilai-nilai sosial yang memberikan banyak manfaat bagi manusia. Selain itu, keagungan Allah lainnya dari kewajiban zakat tersebut ialah hal tersirat berupa kewajiban untuk memiliki kepekaan dan kepedulian sosial kepada sesama manusia. Dengan mewajibkan zakat, secara otomatis Allah mewajibkan manusia untuk memiliki kepedulian dan kepekaan sosial. Dengan demikian, manusia dapat berkasih sayang antara sesamanya dan kesenjangan sosial antara si kaya dan si miskin akan secara otomatis sirna. Inilah karakter yang Allah kehendaki ada pada diri ummat Islam. Ummat yang memiliki kepedulian, kepekaan sosial, saling menyayangi antar sesama, rela berkorban, dan jujur terhadap diri sendiri dan terutama jujur kepada Allah. Dapatlah menjadi keyakinan bagi kita sebagai ummat Islam bahwa hukum yang Allah tentukan kepada manusia bukanlah untuk 


\section{Karebet Gunawan}

kepentingan Allah, melainkan untuk kebaikan dan kemaslahatan manusia itu sendiri (Suharsono, 2013: 70).

Melihat begitu pentingnya zakat maka kita semau harus mau melakukan dan melaksanakan pembayaran zakat, dan umumnya masyarakat dapat melakukan pembayaran melalui dua cara yang banyak dilakukan oleh Muzakki. Dua cara tersebut adalah bagaimana ada orang yang membayarkan zakatnya melalui lembaga zakat, dan ada juga yang membayarkan zakatnya langsung kepada mustahiq. Masing-masing cara tersebut tentu punya beberapa alasan utama seseorang membayar zakat di lembaga zakat misalnya dengan lembaga zakat maka akan tercapai suatu yang sifatnya transparans, dengan lembaga zakat juga lebih kelihatan lebih professional hal ini dikarenakan adanya kantor dan pekerja yang mengerjakan dalam hal menerima dan menyalurkan zakat, kenyamanan karena pasti disalurkan kepada orang-orang yang berhak menerima zakat, begitu juga timbul kemudahan pada saat ada orang yang membayar zakat lewat lembaga zakat, terpengaruh oleh lingkungan dimana dalam lingkungan tersebut banyak yang membayarkan lewat lembaga zakat, dan timbul adanya kepuasan.

Lembaga zakat pada dasarnya dalam memberikan pelayanan haruslah yang pertama haruslah transparan dan bisa menciptakan kepuasaan baik kepuasaan para muzakki maupun para mustahiq sehingga bisa menyebabkan suatu loyalitas yang sangat besar sehingga akan semakin banyak zakat dan wakaf yang diperoleh dan akhirnya disalurkan kepada para mustahiq. Pihak lembaga zakat haruslah berupaya bagaimana bisa menciptakan kepuasaan bagi para muzakki sehingga dana yang diperoleh akan semakin banyak. Selain transparansi harus juga membuat orang-orang yang terlibat dalam lembaga zakat harus puas yang akhirnya akan loyal. Berdasarkan kerangka tersebut maka artikel ini akan membahas hal-hal yang bisa menyebabkan loyalitas yaitu dengan adanya transparansi, kepuasaan dan loyalitas. 


\section{Pembahasan}

\section{Transparansi dalam zakat}

Pemberian zakat melalui salah satu lembaga Amil zakat adalah adanya transparasi. Transparan sebetulnya bisa sama juga dengan Tabligh yaitu untuk mengajak dan sekaligus mampu untuk memberikan contoh kepada pihak lain untuk melaksanakan ketentuan-ketentuan ajaran Islam dalam kehidupan sehari-hari.

Tabligh secara harfiyah memiliki makna menyampaikan sesuatu secara terbuka atau apa adanya dan tanpa di tutuptutupi. Tabligh merupakan suatu sifat yang ada dalam diri nabi Muhammad SAW baik dalam beliau berdakwah maupun dalam berbisnis. Firman Allah SWT: "Supaya Dia mengetahui, bahwa sesungguhnya rasul-rasul itu telah menyampaikan risalah-risalah Tuhannya, sedang (sebenarnya) ilmu-Nya meliputi apa yang ada pada mereka, dan Dia menghitung segala sesuatu satu persatu." (QS. AlJin: 28).

Ayat lain adalah: "Dia (Muhammad) bermuka masam dan berpaling karena telah datang seorang buta kepadanya." (QS. Abasa: $1-2)$

Dalam suatu riwayat dikemukakan bahwa firman Allah di atas turun berkenaan dengan Ibnu Ummi Maktum yang buta yang datang kepada Rasulullah SAW sambil berkata: Berilah petunjuk kepadaku, ya Rasulullah. Pada waktu itu Rasulullah SAW sedang menghadapi para pembesar kaum musyrikin Quraisy, sehingga Rasulullah berpaling daripadanya dan tetap mengahadapi pembesar-pembesar Quraisy. Ummi Maktum berkata: Apakah yang saya katakan ini mengganggu tuan? Rasulullah menjawab: Tidak. Ayat tersebut turun sebagai teguran atas perbuatan Rasulullah SAW. (HR. at-Tirmidzi dan al-Hakim).

Sebetulnya apa yang dilakukan Nabi itu menurut standar umum adalah hal yang wajar. Saat sedang berbicara di depan umum atau dengan seseorang, tentu kita tidak suka diinterupsi oleh orang lain. Namun untuk standar Nabi, itu tidak cukup. 


\section{Karebet Gunawan}

Oleh karena itulah Allah menegurnya. Sebagai seorang yang tabligh, meski ayat itu menyindirnya, Nabi Muhammad tetap menyampaikannya kepada kita. Itulah sifat seorang Nabi.

Tabligh merupakan sifat wajib bagi rasul, yakni menyampaikan wahyu dari Allah SWT kepada umatnya. Semasa hidupnya nabi Muhammad SAW selalu menghabiskan waktunya untuk menyampaikan wahyu kepada umatnya. Setelah nabi muhammad meninggal kebiasaan ini di lanjutkan oleh para sahabat, tabi>it-tabi>in (pengikut-pengikut sahabat). Setelah mereka semuanya tiada kita sebagai mahasiswa muslim mempunyai tanggung jawab untuk meneruskan kebiasaan tabligh yang di lakukan oleh rasul dan para sahabatnya tersebut. Salah satunya adalah dengan mendakwahkan islam dimanapun dia berada. Banyak yang menyangka bahwa tugas tabligh hanyalah tugas alim ulama saja. Hal itu tidak benar karena siapa saja yang melihat kemungkaran di hadapannya maka ia wajib mencegahnya atau menghentikannya, baik dengan tangan (kekuasaan), dengan lisan atau nasihat.

Dengan kemerdekaan sikap memilih, ada dua hal penting yang dapat di pahami; Pertama manusia dapat memilih menjadi muslim atau menjadii kufur, dengan berbagai konsekuensi dan pemahamannya terhadap tauhid, ibadah, dan hubungan muamalah dengan tauhid, ibadah dan muamalah itu sendiri. Manusia yang memilih sebagai muslim, bahwa dia harus dengan sadar bahwa aktifitas bisnis yang di jalankan itu harus sesuai dengan sunnatullah atau menjadi orang yang pasrah kepada Allah. Kedua dengan kelengkapan potensi yang di berikan oleh allah berupa akal pikiran (intelegensi), kemauan, kemampuan kerja (skill), manusia di beri kesempatan untuk mengemban amanah yang sudah di sepakatinya menjadi lebih baik dan mengasah kemampuannya dengan tekun belajar dan memahami perkembangan sains dan teknologi, dan memanfaatkannya untuk kemakmuran masyarakat. Dalam konteks bisnis tablig mencangkup argumentasi dan komunikasi. Sebagai seorang 
penjual hendaklah mampu memasarkan produknya dengan strategi yang tepat, baik dengan media, segmentasi pasar, target daya beli, dan lain sebagainya yang terkait dengan pemasaran. Dengan memiliki sifat tabligh seorang pembisnis di harapkan mampu menyampaikan keunggulan produknya dengan menarik dan tepat sasaran tanpa meninggalkan kejujuran dan kebenaran serta mampu memberikan pemahaman bisnis yang mereka lakukan sesuai dengan syariat Islam.

Semisalkan ada seseorang yang berprofesi sebagai marketer, maka ia harus mampu menyampaikan keunggulankeunggulan produk dengan menarik dan tepat sasaran tanpa meninggalkan kejujuran dan kebenaran (transparency and fairness). Lebih dari itu, seorang marketer harus mempunyai gagasan-gagasan yang baik tentang apa yang di pasarkan dan mampu mengkomunikasikannya secara tepat dan mudah dipahami oleh siapapun yang mendengarkannya. Dengan begitu, pelanggan dapat dengan mudah memahami pesan bisnis yang ingin disampaikan. Dan juga misalkan seorang pemimpin maka dia haruslah mampu menyampaikan visi dan misinya kepada karyawan dan staf-staf lainnya agar bisnisnya bisa berjalan dengan lancar. Sebagaimana firman Allah SWT dalam surat Al-ahzab 7071 yang artinya: “Hai orang-orang yang beriman bertakwalah kamu kepada Allah dan katakanlah perkataan yang benar niscaya Allah akan memperbaiki amalmu-amalmu dan mengampuni bagimu dosa-dosamu, dan barang siapa mentaati Allah dan rasulNya maka sesungguhnya ia telah mendapat kemenangan yang besar." (QS. Al-Ahzab: 70-71).

Alangkah indahnya jika dalam mengelola bisnis kita mempunyai seorang pemimpin, karyawan, dan pemasar yang bisa di percaya karena kesalehan dan kejujurannya, sehingga menjadi contoh bagi siapa yang berkomunikasi dengannya. Seorang pembisnis islami selain mempunyai gagasan-gagasan yang segar dia juda harus mampu mengkomunikasikan gagasn 


\section{Karebet Gunawan}

gagasannya secara tepat dan mudah di pahami bagi siapa yang mendengarkan.

Ayat tersebut mengisyratkan makna bahwa selain harus penyampaian bisnisnya dengan baik, seorang pemimpin juga harus mampu berdialog, berargumentasi, dan berdiskusi dengan baik. Karena sifat tabligh ini di anggap sebagai faktor kunci kesuksesan dalam berbisnis (www.kompasina, 2017).

Sifat tabligh dapat meliputi bijak, sabar, argumentasi dan persuasive sehingga dengan itu semua maka akan menumbuhkan hubungan yang yang solid dan kuat. Adapun indikator dari sifat Tabligh yaitu:

1. Bersifat argumentative. Dalam organisasi apakah perlu adanya argumentasi atau ada cara untuk lain dalam menyampaikan pesan. Argumentasi sebaiknya perlu dilakukan pada pihan waktu dan tempat yang tepat. Usahakan dalam beragumentasi dilakukan di tempat dimana pada posisi yang netral. Untuk membangun argumentasi yang logis sehingga akan dapat mendukung suatu pesan yang akan kita sampaikan kepada seseorang. Ada beberapa hal yang harus kita ketahui apabila kita akan mengadakan suatu argumentasi, yaitu: harus menggunakan bahasa yang jelas, memahami pandangan pihak lain, setiap pelaku usaha maupun para pemegang otoritas yang berkaitan dengan masalah kependudukan perlu memahami tentang konsumen.

2. Menumbuhkan hubungan kemanusiaan yang solid dan cukup kuat. Sesama muslim sebaiknya mempunyai semangat persatuan yang sangat kuat sehingga kemampuan umat Islam sangat solid. Orang Islam yang solid mampu menunjang perekonomian yang menjadikan perekonomian umat Islam bisa bertambah yang berujung pada bertambahnya zakat baik zakat yang akan diterima oleh lembaga amil zakat maupun orang yang berhak menerima zakat atau mustahiq. Zakat sulit diperoleh 
kalau pendapatan masyarakat kurang karena zakat adalah sebagian harta yang wajib dikeluarkan apabila mendapatkan penghasilan yaitu 2,5\% dari perolehan harta. Contoh hubungan manusia yang solid yaitu misalnya ada orang usaha misalnya berdagang kemudian ada orang yang bertanya tentang barang sesuatu sedangkan dia tidak punya maka sebaiknya pedagang tadi menunjukkan dimana tempat barang atau produk tersebut ada sehingga tercipta suatu hubungan yang sangat solid bagi umat Islam dan hal ini rupanya masih kurang bisa didapatkan karena terkadang jumlah yang mayoritas maka kekuataannya malah minoritas beda dengan yang jumlahnya minoritas bisa jadi malah kekuataannya mayoritas. Untuk mendapatkan kekuatan yang solid dan kuat maka sebaiknya pertama adalah adanya satu pemikiran. Ketika orang melakukan pekerjaan maka mempunyai pemikiran bahwa manusia pada dasarnya adalah menjadi khalifah di muka bumi yang akhirnya akan dikembalikan bahwa pekerjaan mereka akan berujung pada kaum muslimin dan kemuliaan umat Islam. Islam tidak melarang orang untuk menjadi kaya tetapi yang tidak diperbolehkan adalah menumpuk-numpuk harta, terlalu cinta dunia dan tidak mau berjuang fisabililah. Umat Islam seharusnya adalah bisa menjadi kaya dan mau bersedekah, berzakat dan berjuang di jalan Allah sehingga bisa menebar rahmat kepada umat Islam. Kalau umat Islam sudah cukup kemudian tidak mau berzakat maka ada ancaman dari Allah SWT.

\section{Pemberian zakat melalui lembaga zakat akan timbul kepuasan.}

Berdasarkan riset BAZNAS dan FEM IPB (2011) tersebut, salah satu alasan utama seseorang membayar zakat di Lembaga Amil Zakat adalah karena adanya faktor kepuasan,dalam arti kepuasan atas kinerja lembaga amil zakat. Sementara, kinerja 


\section{Karebet Gunawan}

Lembaga Amil Zakat dapat diukur dengan mengukur kualitas pelayanan yang diberikan oleh lembaga kepada customer atau biasa disebut dengan service quality (Servqual) (Nurul, 1993: 167). Kualitas pelayanan yang ada pada Lembaga Amil Zakat sebaiknya bagaimana lembaga tersebut bisa memenuhi harapan kebutuhan dari para muzakki dan mustahiq serta memenuhi keinginan yang diharapkan sehingga pelayanan pada lembaga tersebut bisa memenuhi harapan. Muzakki berharap kalau datang ke Lembaga Zakat dapat diterima dengan ramah dan mendapatkan penjelasan yang baik dan begitu juga para mustahiq dapat menerima kehadiran Lembaga Zakat sehingga dalam penerimaan zakat para mutahiq tidak merasa tersinggung.

Kualitas harus dimulai dari kebutuhan masyarakat dan berakhir pada persepsi masyarakat, dalam hal ini muzakki. Sehubungan dengan itu, citra kualitas yang baik bukanlah berdasarkan sudut pandang atau persepsi penyedia jasa yang dalam hal ini Lembaga Amil Zakat, melainkan berdasarkan sudut pandang atau persepsi muzakki. Service quality diharapkan mampu memberikan kepuasan kepada muzaki dan menarik muzakki untuk kembali memiliki kecenderungan melakukan pembayaran zakat secara rutin terhadap jasa yang ditawarkan oleh Lembaga Zakat (Nurul, 1993 : 168).

Supaya lembaga zakat dipercaya oleh masyarakat maka orang-orang yang ada pada lembaga tersebut haruslah beragama Islam karena zakat yang akan diterima adalah semua saling berkaitan antara umat Islam yang satu dengan ummat Islam yang lainnya dengan kepentingan dan urusan kaum muslimin, Mukalaf dalam arti orang-orang yang ada pada lembaga tersebut adalah telah dewasa dimana mereka adalah orang yang sehat baik sehat jasmaninya maupun sehat akal pikirannya yang akhirnya dapat menjalankan tugas sesuai dengan apa yang diharapkan. Orang yang ada di lembaga zakat selain beragama Islam dan mukalaf juga harusnlah orang yang mempunyai sifat yang jujur serta mempunyai tanggung jawab yang tinggi. Kejujuran dalam 
lembaga zakat sangat utama karena berhubungan dengan uang para muzakki yang harus dipegang teguh amanat yang sudah diserahkan jangan sampai tersalurkan kepada orang-orang yang tidak tepat sasaran.

Orang yang berhak menerima zakat adalah fakir dan miskin, pengurus zakat, orang yang baru saja masuk Islam, untuk membebaskan budak, orang yang telilit hutang, orang yang sedang berjuan di jalan Allah dan orang yang sedang dalam bepergian. Fakir dan miskin mempunyai arti yang berbedabeda walaupun umumnya diucapkan dalam satu ucapan. Fakir merupakan orang yang kekurangan dan membutuhkan tetapi dia tidak mau minta-minta kepada orang lain. Miskin adalah orang yang kekurangan dalam mememnuhi kebutuhan hidup tetapi dia mau minta-minta kepada orang lain. Adapun ciri-ciri dari seseorang dikatakan fakir dan miskin adalah orang yang tidak mempunyai harta maupun kekayaan dan tidak mempunyai penghasilan yang cukup atau juga tidak mempunyai pekerjaan, fakir miskin juga bisa mempunyai cirri dimana ada orang yang mempunyai kekayaan dan pekerjaan tetapi pekerjaan yang ia jalankan mendapatkan hasil yang kurang untuk mencukupi dari setengah kebutuhan hidup atau bisa juga diartikan orang yang mempunyai kekayaan dan pekerjaan tetapi hasilnya kurang bisa untuk memenuhi kebutuhan standar dalam hidup.

Selain beragama Islam dan jujur orang yang ada dalam lembaga zakat juga merupakan haruslah orang-orang yang mengerti dan mempunyai kemampuan dalam memahami hukumhukum mengenai zakat dan wakaf sehingga ia mampu untuk mensosialisakan zakat dan wakaf kepada masyarakat baik lewat media tatap muka langsung maupun lewat event-event tertentu misalnya lewat seminar, workshop dll yang bisa mengundang masyarakat luas guna mensosialisasikan zakat sehingga tercapai apa yang diharapkan bagi Lembaga Amil Zakat. Sosialisasi kepada masyarakat memang sangat penting karena selama ini penerimaan zakat lewat Lembaga Amil Zakat masih kurang hal 


\section{Karebet Gunawan}

ini dilihat dari jumlah penduduk di mana mayoritas penduduk Indonesia adalah beragam Islam tetapi penerimaan zakat masih kurang sehingga sangat perlu diadakan sosialisasi.

\section{Kualitas dan loyalitas}

Kualitas sebetulnya dapat kita terima apabila produk maupun jasa mempunyai beberapa keunggulan yaitu bagaimana produk maupun jasa yang ada bisa memenuhi harapan bagi para pengguna dan bagaimana barang tersebut baik tanpa ada kekurangan yang harus diterima oleh pengguna. Sebenarnya barang dapat dikatakan mempunyai kualitas yang baik bila pertama barang tersebut mempunyai karakteristik pokok yang ada pada jasa maupun barang tersebut. Maksud dari karakteristik pokok adalah bagaimana dapat menjalankan sebagaimana fungsinya. Misalnya saja pada lembaga zakat dapat menjalankan sebagaimana fungsinya yaitu menyalurkan zakat yang diperoleh dari para Muzakki dengan tepat sasaran kapada para mustahiq sesuai dengan criteria yang ada sehingga zakat tepat sasaran dan bisa memberikan manfaat yang baik, baik buat muzakki maupun mustahiq. Contoh yang paling mudah dikatakan berkualitas apabila sesuai dengan karakteristik pokok barang atau produk tersebut adalah apabila membuat televise maka karakteristik pokok salah satunya adalah bagaimana ketajaman gambar yang ada kalau televise tersebut kurang ketajaman gambarnya maka bisa dikatakan televise tersebut kurang berkualitas.

Kedua setelah karakteristik pokok barang atau jasa dikatakan berkualitas apabila mempunyai beberapa fuature yaitu tambahan-tambahan atau fitur-fitur tambahan. Misalnya saja dalam lembaga zakat membuka rekening sehingga masyarakat akan semakin mudah menyalurkan zakatnya tanpa harus datang ke lokasi atau kantor lembaga zakat. Contoh yang paling mudah dipahami pada barang yang ada futurenya adalah kendaraan maka kendaraan tersebut ada power window, power stering, double stater dan lainnya. 
Ketiga dikatakan berkualitas bila ada pelayanan purna jual maka pada lembaga zakat sebaiknya juga ada istilah pelayanan purna jual yaitu dalam arti pelayanan setelah ada Muzakki yang yang menempatkan zakatnya pada lembaga zakat maka lembaga tersebut sebaiknya menghubungi atau menginformasikan kepada para Muzakki bahwa zakatnya telah diterima dan disalurkan kepada siapa saja harus diberitahukan kepada para Muzakki agar mereka merasa puas sehingga merujuk kepada loyalitas.

Keempat yaitu service. Service disini dalam arti pelayanan yaitu bagaimana Lembaga Amil Zakat mampu memberikan service yang baik misalnya saja petugas amil zakat berkunjung atau dalam istilah pemasaran melakukan jemput bola kepada para Muzakki dan memberikan keterangan misalnya apabila ada muzakki yang transfer maka petugas amil zakat memberitahukan bahwa telah menerima zakat yang telah diberikan kepada Lembaga Zakat. Amil zakat, yang secara tekstual terdapat dalam surat at-Taubah ayat 60 , memiliki peran yang sangat penting,baik dalam pengumpulan dan pendistribusian zakat, maupun dalam usaha melakukan pendayagunaan ekonomi masyarakat untuk tercapainya kesejahteraan dan terbebas dari kemiskinan (Nurul, 1993: 171).

Dalam khazanah hukum Islam, yang bertugas mengambil dan yang menjemput zakat adalah para petugas zakat (amil). Menurut Imam Qurthubi, amil adalah orang-orangyang ditugaskan (diutus oleh imam/pemerintah) untuk mengambil, menuliskan, menghitung, dan mencatat atas harta zakat yang diambil dari para muzaki untuk kemudian diberikan kepada yang berhak menerimanya. Hal yang samadikemukakan Ibn Hazm mengatakan bahwa amil zakat adalah para pekerja zakatyangdiutus oleh imam yang wajib untuk menaatinya, yaitu mereka yang bisa dibenarkan (dipercaya) dan mereka yang menjadi pengumpul zakat (Nurul, 1993: 172).

Islam mengajarkan bila ingin memberikan hasil usaha baik berupa barang maupun pelayanan/jasa hendaknya memberikan 


\section{Karebet Gunawan}

yang berkualitas, jangan memberikan yang buruk atau tidak berkualitas kepada orang lain. Allah SWT, berfirman dalam surat al-Baqarah ayat 267: “Orang-orang yang beriman, naftahkanlah (di jalan Allah) sebagian dari hasil usahamu yang baik-baik dan sebagian dari apa yang Kami keluarkan dari bumi untuk kamu. Dan janganlah kamu memilih yang buruk-buruk lalu kamu menafkahkan daripadanya, padahal kamu sendiri tidak mau mengambilnya melainkan dengan memincingkan mata terhadapnya. Dan ketahuilah, bahwa Allah Maha Kaya lagi Maha Terpuji." (QS. Al-Baqarah: 267).

Dimensi kualitas jasa dalam model SERVQUAL didasarkan pada skala multi-item yang dirancang untuk mengukur harapan dan persepsi pelanggan, serta gap di antarakeduanya dalam dimensi-dimensi kualitas jasa. Pada awalnya Parasuraman et al., (1985) mengidentifikasi sepuluh dimensi pokok dengan 22 variabel yang berkaitan dengan pelayanan dan kemudian dianalisis dengan memakai analisis faktor. Ternyata dapat dikemukakan beberapa kriteria yang digunakan dalam menilai mutu pelayanan. Kriteria tersebut meliputi 10 dimensi potensial yang saling melengkapi yaitu tangibles, reliability, responssiveness, communication, credibility, security, competence, courtesy, understanding dan access (Nurul, 1993: 177).

Dimensi SERVQUAL yang diusulkan oleh Parasuramanet et. al., (1988) ada lima yaitu assarance, reliability, tangibility, empathy, dan responssiveness. Dimensi kualitas pertamaadalah assuranceberkaitan dengan pengetahuan, sopan santun, dan kemampuan pegawai dalam menyampaikan kebenaran dan meyakinkan. Dimensi kedua, reliability yangterkait dengan kemampuan perusahaan dalam menyediakanpelayanan yang dapat diandalkan dan akurat. Dimensi ketiga, tangibility berkaitan dengan fasilitas, peralatan danpenampilan personel secara fisik. Dimensi keempat adalahempathy berkaitan dengan tingkat penjagaan dan perhatianyang disediakan bagi konsumen. Adapun dimensi kelimaadalah resp onssiv eness yang berhubungan 
dengan keinginanperusahaan untuk membantu konsumen dan menyediakanpelayanan yang cepat dan tepat (Nurul, 1993: 178).

Dengan adanya pelayanan yang sangat baik maka konsumen pada lembaga zakat akan semakin loyal. Loyalitas bisa menyebabkan Muzakki akan ada keterikatan dengan lembaga zakat terutama pada program-program yang akan diterapkan. Selain itu dengan adanya loyalitas pelanggan maka pelanggan tersebut akan datang dan membeli barang atau jasa secara terus menerus makin lama makin banyak dan juga akan menceritakan kepada orang lain. Lembaga zakat apabila orang-orang yang ada di dalamnya bisa menciptakan suatu loyalitas yang baik buat Muzakki maka akan diperoleh hasil zakat dan wakaf yang sangat banyak sehingga semakin lama semakin maju. Kemajuan lembaga tersebut akan berujung pada kemakmuran masyarakat pada umumnya khususnya adalah para uamt Islam yang menempati mayoritas jumlah penduduk di negara kita. Pelanggan dapat dikatakan loyal bila pelanggan tersebut bisa menyebarkan berita yang baik kepada orang lain mengenai suatu jasa/ produk. Sebetulnya berita yang baik akan bisa menjadikan suatu rekomendasi yang menjadi bagi keputusan untuk melakukan pembelian baik pembelian suatu jasa atau produk yang akan disalurkan kepada orang lain sehingga orang lain tertarik pada produk tersebut.

\section{Simpulan}

Allah SWT mendorong kaum muslimin untuk membayar zakat dengan menjelaskan manfaat zakat bagi kebersihan jiwanya. Zakat akan memberikan dampak positif baik bagi pemberi maupun bagi yang menerima. Melihat begitu pentingnya zakat maka kita semau harus mau melakukan dan melaksanakan pembayaran zakat, dan umumnya masyarakat dapat melakukan pembayaran melalui dua cara yang banyak dilakukan oleh Muzakki. Dua cara tersebut adalah ada orang yang membayarkan zakatnya melalui lembaga zakat, dan ada juga yang membayarkan zakatnya 


\section{Karebet Gunawan}

langsung kepada mustahiq. Untuk menjamin kelangsungan kalau membayar lewat lembaga zakat maka perlu adanya loyalitas bagi para muzakki. Dan untuk menumbuhkan loyalitas perlu adanya suatu transparansi, pelayanan dan kualitas yang baik. Transparansi bisa dibentuk dengan adanya salah satu sifat bagi orang-orang yang bertugas di lembaga zakat, yaitu haruslah mempunyai sifat tabligh. Sifat tabligh dapat meliputi bijak, sabar, argumentatif dan persuasive sehingga dengan itu semua akan menumbuhkan hubungan yang yang solid dan kuat antara muzakki dan lembaga zakat. Dengan adanya pelayanan yang sangat baik maka pengguna pada lembaga zakat akan semakin loyal. Loyalitas bisa menyebabkan muzakki akan ada keterikatan dengan lembaga zakat terutama pada program-program yang akan diterapkan.

\section{Daftar Pustaka}

A. Parasuraman, Zethamal, VA., \& Berry, L.L., SERQUAL; a multiple item scale for measuring consumer perpceptions of service quality, Journal of Retailing, 1998

Hafid Fuad Halimi, Bersyukur dengan Zakat, Adfale, Semarang, 2013.

https://www.kompasiana.com.

Ippo Santosa, Muhammad Sebagai Pedagang, Gramedia, Jakartaa, 2009.

Mulyadi Nitisusastro, Perilaku Konsumen, Alfabeta, Yogyakarta, 2013.

Nurul Huda, Zakat Perspektif Mikro-Makro, Prenadamedia Group, Jakarta, 1993.

Suharsono, Komunikasi Bisnis, Alfabeta, Yogyakarta, 2013. 